\title{
THE INFLUENCE OF CEREAL SHARE IN CROP ROTATIONS ON THE GRAIN YIELD AND QUALITY OF WINTER WHEAT
}

\author{
MÁRIA BABULICOVÁ*, SOŇA GAVURNÍKOVÁ \\ National Agricultural and Food Centre - Research Institute of Plant Production, Piešt'any
}

BABULICOVÁ, M. - GAVURNÍKOVÁ, S.: The influence of cereal share in crop rotations on the grain yield and quality of winter wheat. Agriculture (Pol'nohospodárstvo), vol. 61, 2015, no. 1, pp. 12-21.

The aim of our study is to find out the influence of differ-
ent share of cereals and various fertilisation on the grain
yield and quality of winter wheat. The long-term field trial
with 40,60 and $80 \%$ share of the cereals and two levels
of fertilisation $\left(\mathrm{H}_{1}\right.$ mineral fertilisation + organic manu-
re Veget ${ }^{\circledR} ; \mathrm{H}_{2}$ mineral fertilisation only) were carried out
in the very warm and dry area of continental weather on
luvi-haplic chernozem. In the years $2010-2013$, the grain
yield, the wet gluten content, gluten index, the falling
number and sedimentation index of winter wheat accord-

Key words: falling number, fertilisation, gluten index, sedimentation index, preceding crop, wet gluten

Crop rotations in Slovakia are constantly adapted to economic conditions and political intentions. Crop rotation is especially important in agricultural cooperative farms that are aimed at growing one or two main crops. In these farms, so-called 'free crop rotation' is applied. It means that crop rotation is dependent on the market mechanism of present time. The damage by fungus diseases, strong pressure of weed infestation, the deterioration of soil structure and negative impact on soil water and air regime are reasons of grain yield depression in free crop rotation. The correct crop rotation utilises the specific ability of some species of crops to favourably influence physical, chemical and biological properties of the soil. The optimisation of grain yield and quality of winter wheat are dependent not only on the appropriate crop rotation but also on the nitrogen fertilisation. It influences the biomass, the accumulation and distribution of nitrogen in particular plan ing to Zeleny were investigated. The significantly higher grain yield of winter wheat was recorded after preceding crop of common pea. The yield of cereals in crop rotation with $60 \%$ share of cereals $(7.00 \mathrm{t} / \mathrm{ha}$ ) was significantly higher than in crop rotation with $80 \%$ share of cereals $(6.78 \mathrm{t} / \mathrm{ha})$. The statistically higher wet gluten content after pea forecrop was found out when the mineral fertilisation and organic fertiliser Veget ${ }^{\circledR}$ were applied $(33.4 \%)$ with comparison to the treatment with mineral fertilisation only $(30.08 \%)$. parts (Zhou et al. 2013). N fertilisation increases the total quantity of flour proteins, resulting in a rise in both gliadins and glutenins. The identical grain yield of winter wheat was reached by fertilisation with nitrogen in $\mathrm{NH}_{4}^{+}$form as well as by fertilisation with nitrogen in $\mathrm{NO}_{3}^{-}$form. Nitrogen in $\mathrm{NO}_{3}^{-}$ form can be used by plants to growth stage $\mathrm{BBCH}$ 37 (Fuertes-Mendizabal et al. 2013). Genotype $\times \mathrm{N}$ interactions was significant for yield, grain protein content, $\mathrm{N}$ concentration in straw, $\mathrm{N}$ utilisation, and nitrogen use efficiency (Cormier et al. 2013). The composition of protein determines the nutritional value and baking properties of wheat grain. The changes in protein composition are mainly influenced by the genotype, the environment, and the interaction among the genotype, environment and fertilisation (Stepien \& Wojtkowiak 2013). Differences between hard and soft genotypes appeared to be significant, apart from grain hardness, for pro-

Ing. Mgr. Mária Babulicová, PhD. (*Corresponding author), National Agricultural and Food Centre/Research Institute of Plant Production, 92168 Piešt’any, Bratislavská cesta 122, Slovak Republic. E-mail: babulicova@vurv.sk 
tein content, Zeleny test and alveograph parameter (Surma et al. 2012). Long-term trials serve as monitoring system in solving the problem of permanent decreasing of crop productivity.

The aim of our research is to investigate the influence of share of cereals in crop rotations $(40,60$ and $80 \%)$ and fertilisation $\left(\mathrm{H}_{1}-\right.$ mineral fertilisation + organic manure Veget ${ }^{\circledR}$ incorporation; $\mathrm{H}_{2}-$ mineral incorporation) on the grain yield and quality of winter wheat. The research was realised in 2010-2013 in the long-term field trial. The trial was established in 1974 at Experimental station Borovce, which belongs to Research Institute of Plant Production in Pieštany.

\section{MATERIAL AND METHODS}

Long-term field trial is situated on Luvi-Haplic Chernozem, $\mathrm{pH}$ 5.5-7.2, the humus content $1.8-2.0 \%$. The area has continental pattern of climate with long-term average sum of annual rainfall of $593 \mathrm{~mm}$ and $358 \mathrm{~mm}$ rainfall during vegetation period. Long-term average of annual temperature is $9.2^{\circ} \mathrm{C}$, in vegetation period $15.5^{\circ} \mathrm{C}$ (Table 1 ). In the field experiment, there were crop rotations with 40,60 and $80 \%$ proportion of cereals. Crops in different crop rotation are presented in Table 2. The fertilisation level $\mathrm{H}_{1}$ : fertilisation by phosphorus and potassium was carried out by balance method according to Bizík et al. (1998). Nitrogen fertilisation was used according to the content of nitrogen in soil (soil samples were taken from $0.0-0.3 \mathrm{~m}$ of soil profile) + organic manure Veget ${ }^{\circledR}$ in dose of $5 \mathrm{t} / \mathrm{ha}$. The content of nitrogen in the soils and in the plants of winter wheat is presented in Table 3. In Table 4, there are doses of nitrogen applied per hectare in the form of fertiliser ammonium calcific saltpetre (content of N 27\%). The composition of organic fertiliser Veget $^{\circledR}$ is as follows: dry matter content min. $85 \%$ (includes combustible matter content $75 \%$; total $\mathrm{N}$ content 2.5-3.0\%; total $\mathrm{P}_{2} \mathrm{O}_{5}$ content $0.5-2.0 \%$, and

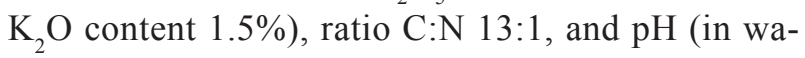
ter) 8.5 . Veget ${ }^{\circledR}$ is produced by The Cleaning device of Waste water in Čebovce. It is a branch of Biotika a.s. Slovenská L'upča. The fundamental crude material of Veget ${ }^{\circledR}$ is composed of sludge from threonine, penicillin and amino acids production and the concentrated sludge from waste water cleaning device following anaerobic processing. The fertilisation

$\mathrm{T}$ a

Weather conditions in the experimental years 2010-2013 on the stand Borovce

\begin{tabular}{|l|c|c|c|r|r|r|r|r|r|r|}
\hline \multirow{4}{*}{ Month } & \multicolumn{2}{|c|}{$\mathrm{n}(1951-1980)$} & \multicolumn{2}{|c|}{2010} & \multicolumn{2}{|c|}{2011} & \multicolumn{2}{|c|}{2012} & \multicolumn{2}{c|}{2013} \\
\cline { 2 - 11 } & $\mathrm{x}_{\mathrm{td}}$ & $\sum$ & $\mathrm{x}_{\mathrm{td}}$ & $\sum$ & $\mathrm{x}_{\mathrm{td}}$ & $\sum$ & $\mathrm{x}_{\mathrm{td}}$ & $\sum_{\mathrm{z}}$ & $\mathrm{x}_{\mathrm{td}}$ & $\sum$ \\
\cline { 2 - 11 } & {$\left[{ }^{\circ} \mathrm{C}\right]$} & {$[\mathrm{mm}]$} & {$\left[{ }^{\circ} \mathrm{C}\right]$} & {$[\mathrm{mm}]$} & {$\left[{ }^{\circ} \mathrm{C}\right]$} & {$[\mathrm{mm}]$} & {$\left[{ }^{\circ} \mathrm{C}\right]$} & {$[\mathrm{mm}]$} & {$\left[{ }^{\circ} \mathrm{C}\right]$} & {$[\mathrm{mm}]$} \\
\hline January & -1.8 & 32 & -2.22 & 60.6 & -1.87 & 32.4 & -0.48 & 78.8 & -2.55 & 69.8 \\
February & 0.2 & 33 & 1.39 & 38.0 & -2.06 & 8.0 & -4.59 & 39.2 & -0.77 & 90.3 \\
March & 4.2 & 32 & 4.82 & 19.5 & 4.31 & 29.0 & 5.07 & 4.5 & 0.84 & 75.3 \\
April & 9.4 & 43 & 9.91 & 65.0 & 11.6 & 30.4 & 9.07 & 20.3 & 9.15 & 17.4 \\
May & 14.1 & 54 & 15.41 & 168.3 & 14.68 & 93.2 & 15.43 & 16.2 & 13.52 & 67.4 \\
June & 17.7 & 80 & 19.47 & 95.0 & 19.15 & 165.2 & 18.88 & 108.1 & 17.51 & 70.1 \\
July & 18.9 & 76 & 23.02 & 98.0 & 18.14 & 83.2 & 20.73 & 94.1 & 20.71 & 3.0 \\
August & 18.4 & 68 & 19.65 & 99.5 & 20.48 & 25.4 & 20.12 & 10.6 & 20.12 & 112.9 \\
September & 14.5 & 38 & 13.42 & 101.5 & 16.41 & 17.8 & 14.76 & 41.5 & 11.59 & 75.6 \\
October & 9.6 & 42 & 8.04 & 25.0 & 7.77 & 32.9 & 8.02 & 88.5 & 8.71 & 29.1 \\
November & 4.6 & 51 & 7.36 & 76.0 & 1.37 & 2.0 & 4.88 & 22.6 & 3.33 & 59.7 \\
December & 0.3 & 46 & -2.23 & 48.8 & 0.03 & 42.4 & -2.81 & 46.5 & -0.57 & 9.9 \\
\hline $\mathrm{x}_{\mathrm{td}}\left[{ }^{\circ} \mathrm{C}\right]$ & 9.2 & - & 9.84 & - & 9.17 & - & 9.09 & - & 8.47 & - \\
\hline$\sum_{\mathrm{z}}[\mathrm{mm}]$ & - & 595 & - & 895.2 & - & 561.9 & - & 570.9 & - & 680.4 \\
\hline
\end{tabular}

$\mathrm{n}$ - long-term (30-year) normal; $\mathrm{x}_{\mathrm{td}}-$ average air temperature; $\sum$ - sum of precipitation 
level $\mathrm{H}_{2}$ : fertilisation of phosphorus, potassium and nitrogen was applied at the same level as $\mathrm{H}_{1}$ except organic manure Veget ${ }^{\circledR}$. Winter wheat variety Petrana was used.

Wet gluten content and gluten index were determined according to ICC Standard No.155 (Glutomatic 2200, Perten Instruments, Sweden). The gluten index (GI) is a method of analysing wheat protein that provides simultaneous determination of gluten quality and quantity. The GI value expresses a weight percentage of the wet gluten remaining on sieves after automatic washing in salt solution and centrifugation (Centrifuge 2015, Perten Instruments, Sweden). GI allows a reliable prediction of bread-making quality. Zeleny sedimentation index was determined according to STN ISO 5529, 2008
(Shaker Brabender, Germany) and falling number according to STN EN ISO 3093, 2010 (falling number 1800, Perten Instruments, Sweden). Analyses of all parameters were realised in two replications. The data was computed by multi-way analysis of variance (ANOVA) and the least significant difference ( $L S D$ ) multiple range test was used at the $0.05 \%$ level. STATISTICA 6. 1 (StatSoft Inc., Tulsa, USA) software was used.

\section{RESULTS AND DISCUSSION}

In 2010-2013, average monthly temperatures and monthly sum of monthly rainfall (Table 1) differed from the long-term average (1951-1980). In

T a b 1 e 2

The crop rotations with 40,60 and $80 \%$ share of the cereals

\begin{tabular}{|l|l|l|}
\hline \multicolumn{2}{|c|}{ Crop rotation } \\
\hline $40 \%$ share of cereal & $60 \%$ share of cereal & $80 \%$ share of cereal \\
\hline 1. Pea & 1. Pea & 1. Winter wheat \\
2. Winter wheat & 2. Winter wheat & 2. Spring barley \\
3. Silage maize & 3. Winter barley & 3. Pea \\
4. Spring barley & 4. Silage maize & 4. Winter wheat \\
5. Grain maize & 5. Spring barley & 5. Winter barley \\
\hline
\end{tabular}

T

The content of nitrogen in the soil and the plant of winter wheat in years 2009-2013

\begin{tabular}{|c|c|c|c|c|c|c|c|c|c|c|}
\hline \multirow{3}{*}{$\begin{array}{c}\text { SCCR } \\
{[\%]}\end{array}$} & \multirow{3}{*}{$\mathrm{PC}$} & \multirow{3}{*}{$\mathrm{F}$} & 2009 & \multicolumn{2}{|c|}{2010} & \multicolumn{2}{|c|}{2011} & \multicolumn{2}{|c|}{2012} & \multirow{2}{*}{$\begin{array}{c}2013 \\
\text { Spring } \\
\text { plants }\end{array}$} \\
\hline & & & $\begin{array}{c}\text { Autumn } \\
\text { soil }\end{array}$ & $\begin{array}{l}\text { Spring } \\
\text { plants }\end{array}$ & $\begin{array}{c}\text { Autumn } \\
\text { soil }\end{array}$ & $\begin{array}{l}\text { Spring } \\
\text { plants }\end{array}$ & $\begin{array}{c}\text { Autumn } \\
\text { soil }\end{array}$ & $\begin{array}{l}\text { Spring } \\
\text { plants }\end{array}$ & $\begin{array}{c}\text { Autumn } \\
\text { soil }\end{array}$ & \\
\hline & & & {$[\mathrm{mg} / \mathrm{kg}]$} & {$[\mathrm{g} / \mathrm{kg}]$} & {$[\mathrm{mg} / \mathrm{kg}]$} & {$[\mathrm{g} / \mathrm{kg}]$} & {$[\mathrm{mg} / \mathrm{kg}]$} & {$[\mathrm{g} / \mathrm{kg}]$} & {$[\mathrm{mg} / \mathrm{kg}]$} & {$[\mathrm{g} / \mathrm{kg}]$} \\
\hline \multirow{2}{*}{40} & \multirow{2}{*}{ pea } & $\mathrm{H}_{1}$ & 7.1 & 25.4 & 6.3 & 30.2 & 4.52 & 30.6 & 7.6 & 31.9 \\
\hline & & $\mathrm{H}_{2}$ & 8.3 & 23.2 & 7.1 & 28.7 & 3.07 & 23.9 & 8.0 & 30.2 \\
\hline \multirow{2}{*}{60} & \multirow{2}{*}{ pea } & $\mathrm{H}_{1}$ & 12.4 & 23.9 & 4.7 & 29.6 & 3.98 & 22.4 & 3.8 & 27.9 \\
\hline & & $\mathrm{H}_{2}$ & 11.8 & 25.2 & 4.9 & 31.4 & 5.44 & 31.8 & 2.3 & 30.3 \\
\hline \multirow{4}{*}{80} & \multirow{2}{*}{ pea } & $\mathrm{H}_{1}$ & 6.3 & 22.9 & 3.2 & 25.4 & 4.77 & 28.0 & 2.7 & 28.1 \\
\hline & & $\mathrm{H}_{2}$ & 7.4 & 24.5 & 3.4 & 23.2 & 3.61 & 25.1 & 2.2 & 29.5 \\
\hline & \multirow{2}{*}{ WB } & $\mathrm{H}_{1}$ & 3.7 & 23.8 & 3.3 & 23.2 & 3.86 & 22.2 & 2.5 & 31.1 \\
\hline & & $\mathrm{H}_{2}$ & 4.5 & 25.1 & 3.5 & 22.9 & 4.97 & 30.2 & 2.3 & 28.5 \\
\hline
\end{tabular}

SCCR - share of cereals in crop rotation; PC - preceding crop; $\mathrm{F}$ - fertilisation; $\mathrm{H}_{1}-$ mineral fertilisation + organic manure Veget ${ }^{\mathbb{B}} ; \mathrm{H}_{2}$ - mineral fertilisation; WB - winter barley 
2010, the growth of winter wheat was negatively influenced by the abnormal rainfall in May (sum of rainfall in May was by $114.3 \mathrm{~mm}$ higher than in the long-term average). In 2011, the monthly sum of rainfall in May was higher by $39.2 \mathrm{~mm}$ than longterm average. The monthly sum of rainfall in June was higher by $85.2 \mathrm{~mm}$ than long-term average. Year 2012 was unfavourable for winter wheat growth, too. After strong freezing temperatures in February, three very dry months (March, April, May) followed (Table 1). In February, the average monthly temperature was lower by $4.61^{\circ} \mathrm{C}$ than long-term average. The monthly sum of rainfall in March was lower by $27.5 \mathrm{~mm}$ than long-term average. The monthly sum of rainfall in April was lower by $22.7 \mathrm{~mm}$ than longterm average. The monthly sum of rainfall in May

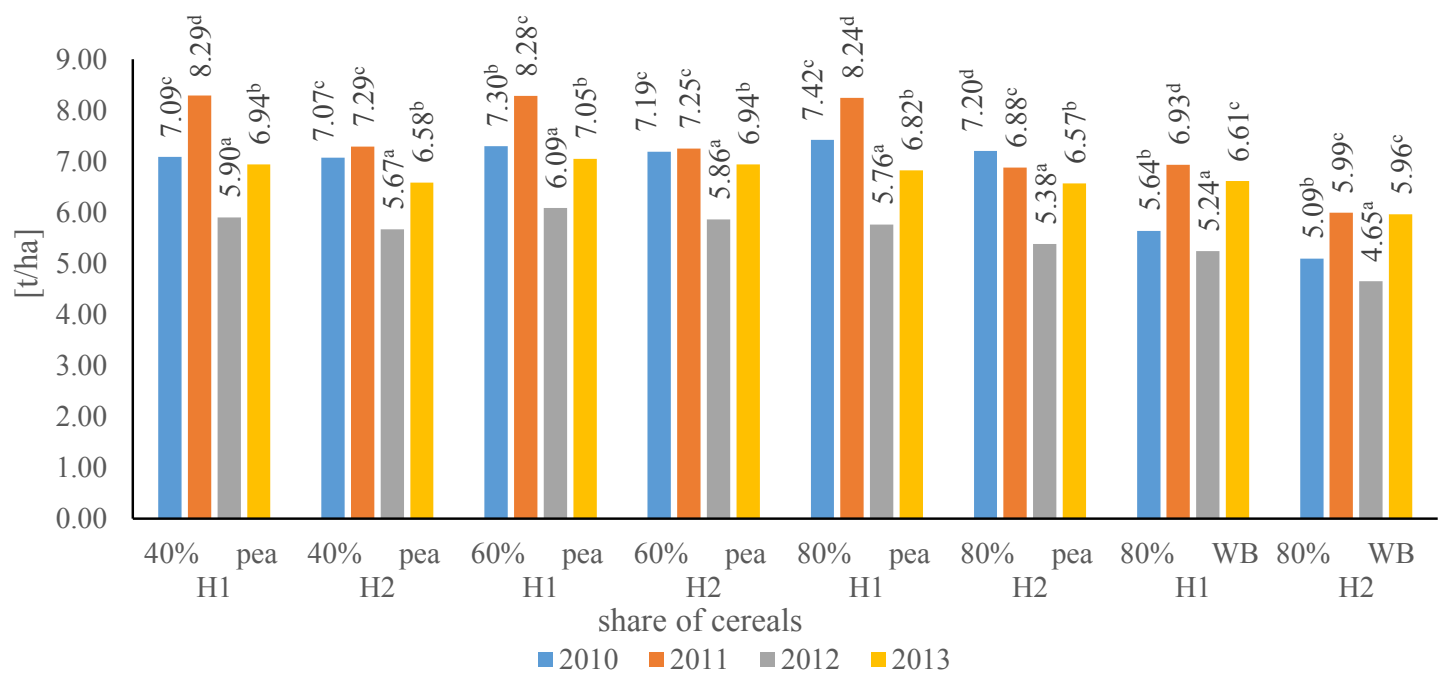

Figure 1 . The grain yield of winter wheat $[\mathrm{t} / \mathrm{ha}]$ in crop rotations with different share of cereals (abbreviations see Table 4)

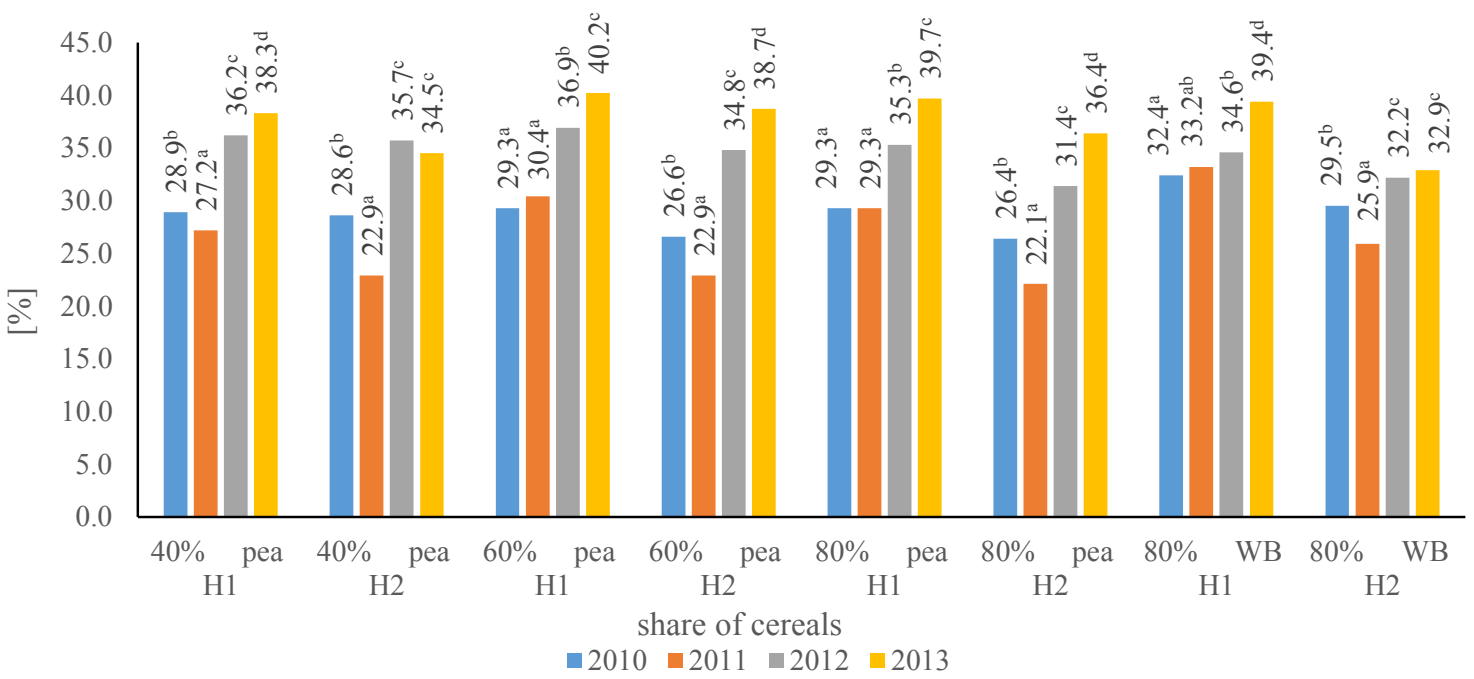

Figure 2. The wet content [\%] of winter wheat grain in crop rotations with different share of cereals (abbreviations see Table 4) 
was lower by $37.8 \mathrm{~mm}$ than long-term average. Years 2011 and 2013 were more favourable than 2010 and 2012 from the point of winter wheat development stand. Weather conditions of particular years were the most important factor affecting the grain yield of winter wheat. The difference in average grain yield in 2011 and 2012 constituted 1.52 t/ha. Similarly, Burešová and Palík (2009) observed the dependence of grain yield and baking quality from the progress of weather in vegetation period. Quality of winter wheat grain was better in years with higher temperature and lower precipitation during the vegetation period. They mentioned that the highest dependence from the weather progress was found out by following parameters: falling number, volume weight and the content of nitrogen substances. Volume weight was influenced by temperature more than by precipitation. The negative influence of precipitation to falling number was manifested in the period of full maturity. The content of nitrogen substances was influenced by the temperature and precipitation in June and July. Garrido-Lestache

T a b

The fertilisation of winter wheat $[\mathrm{kg} / \mathrm{ha}]$ - foundation fertilisation in the autumn and additional fertilisation (regeneration and production) in the spring

\begin{tabular}{|c|c|c|c|c|c|c|c|c|c|c|c|c|c|c|}
\hline \multirow{2}{*}{ SCCR [\%] } & \multirow{2}{*}{$\mathrm{PC}$} & \multirow{2}{*}{$\mathrm{F}$} & 2009 & \multicolumn{3}{|c|}{2010} & \multicolumn{3}{|c|}{2011} & \multicolumn{3}{|c|}{2012} & \multicolumn{2}{|c|}{2013} \\
\hline & & & GF & $\mathrm{RF}$ & $\mathrm{PF}$ & GF & RF & $\mathrm{PF}$ & GF & RF & $\mathrm{PF}$ & GF & $\mathrm{RF}$ & PF \\
\hline \multirow{2}{*}{40} & \multirow{2}{*}{ pea } & $\mathrm{H}_{1}$ & 30 & 45 & 45 & 30 & 45 & 30 & 45 & 45 & 30 & 30 & 45 & 30 \\
\hline & & $\mathrm{H}_{2}$ & 30 & 45 & 45 & 30 & 45 & 30 & 45 & 45 & 45 & 30 & 45 & 30 \\
\hline \multirow{2}{*}{60} & \multirow{2}{*}{ pea } & $\mathrm{H}_{1}$ & 15 & 30 & 45 & 45 & 45 & 30 & 45 & 45 & 45 & 45 & 45 & 30 \\
\hline & & $\mathrm{H}_{2}$ & 15 & 30 & 45 & 45 & 45 & 30 & 30 & 45 & 30 & 45 & 45 & 30 \\
\hline \multirow{4}{*}{80} & \multirow{2}{*}{ pea } & $\mathrm{H}_{1}$ & 30 & 45 & 45 & 45 & 45 & 45 & 45 & 45 & 30 & 45 & 45 & 30 \\
\hline & & $\mathrm{H}_{2}$ & 30 & 45 & 45 & 45 & 45 & 45 & 45 & 45 & 45 & 45 & 45 & 30 \\
\hline & \multirow{2}{*}{ WB } & $\mathrm{H}_{1}$ & 45 & 45 & 45 & 45 & 45 & 45 & 45 & 45 & 45 & 45 & 45 & 30 \\
\hline & & $\mathrm{H}_{2}$ & 45 & 45 & 45 & 45 & 45 & 45 & 45 & 45 & 30 & 45 & 45 & 30 \\
\hline
\end{tabular}

SCCR - share of cereals in crop rotation; PC - preceding crop; F - fertilisation; GF - ground fertilisation; $\mathrm{RF}$ - regeneration fertilisation; $\mathrm{PF}$ - production fertilisation; $\mathrm{H}_{1}-$ mineral fertilisation + organic manure Veget $^{\mathbb{B}} ; \mathrm{H}_{2}-$ mineral fertilisation; WB - winter barley

T a b 1 e 5

The influence of fertilisation and share of cereals on the grain yield of winter wheat (analysis of variance)

\begin{tabular}{|l|c|c|c|c|c|}
\hline \multirow{2}{*}{ Factor } & \multicolumn{5}{|c|}{ Grain yield [t/ha] } \\
\cline { 2 - 5 } & $d f$ & MS & F & $P$ & $L S D_{0.05}$ \\
\hline Fertilisation (A) & 1 & 4.66 & 3.99 & ++ & 0.12 \\
SCCR (B) & 2 & 0.37 & 3.14 & + & 0.18 \\
$\mathrm{~A} \times \mathrm{B}$ & 2 & 0.07 & 3.14 & - & - \\
Years (C) & 3 & 16.14 & 2.75 & ++ & 0.23 \\
$\mathrm{~A} \times \mathrm{C}$ & 3 & 1.30 & 2.75 & ++ & 0.52 \\
$\mathrm{~B} \times \mathrm{C}$ & 6 & 0.13 & 2.24 & - & - \\
Total & 95 & 0.69 & - & - & - \\
Error & 69 & 0.93 & - & ++ \\
\hline
\end{tabular}

SCCR - share of cereals in crop rotation; $d f$ - degrees of freedom; MS - average squares, $\mathrm{F}-\mathrm{F}$-test; $P$ - effect of a factor significant at the level $0.05 ; L S D_{0.05}$ - least significant difference at the level $\alpha=0.05$ 
et al. (2004) reported that a close correlation was observed between rainfall over the September-May period and both grain yield and grain protein content (optimum values for both being recorded in the rainfall range $500-550 \mathrm{~mm}$ ) as well as the alveogram index. López-Bellido et al. (2001) mentioned that grain protein content increased with rainfall in the month of May (when grain protein accumulation occurs) up to a maximum of $80 \mathrm{~mm}$. Grain protein content peaked at average mean temperatures of around $26-27^{\circ} \mathrm{C}$.

The highest grain yield of winter wheat $(8.29 \mathrm{t} / \mathrm{ha})$ was reached in 2011 in crop rotation with $40 \%$ share of cereals with the level of fertilisation $\mathrm{H}_{1}$ (Figure 1). The grain yield of winter wheat growing after preceding crop pea, was statistically significantly influenced by fertilisation, share of cereals in crop rotations, weather in particular years, by interac-

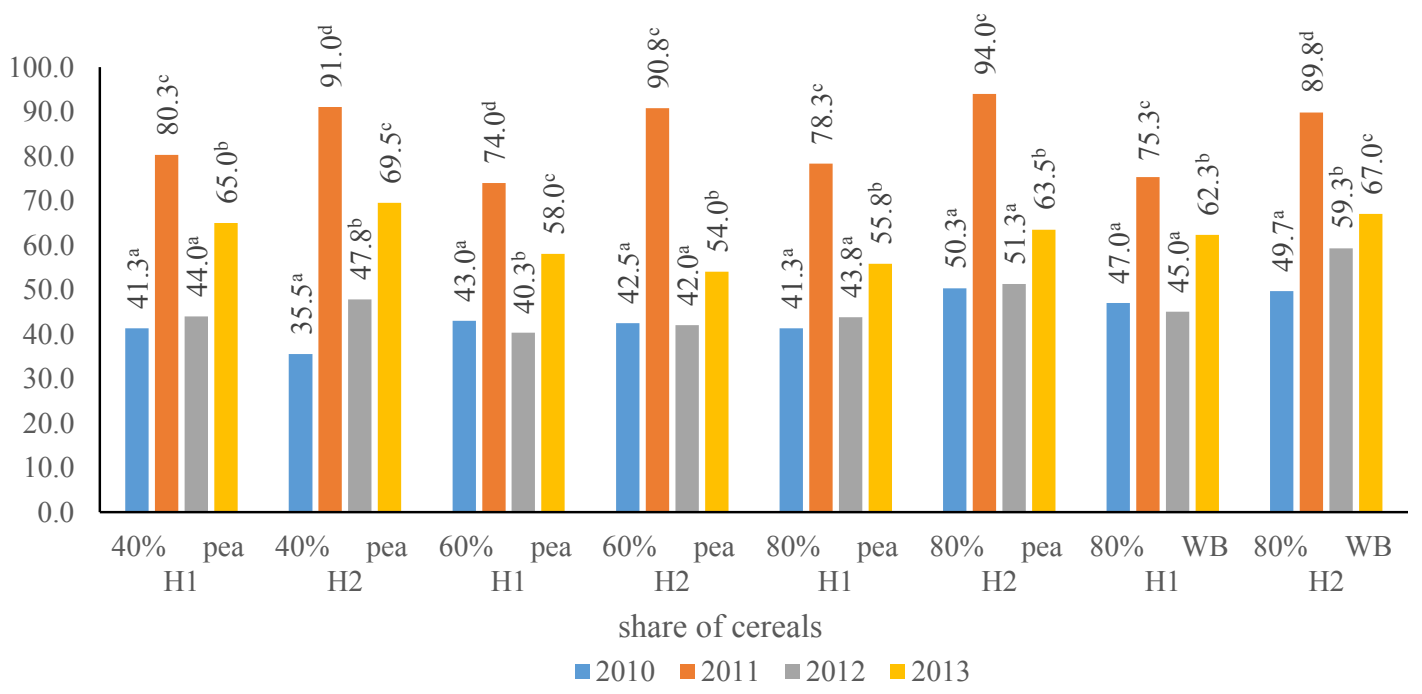

Figure 3. Gluten index of winter wheat grain in crop rotations with different share of cereals (abbreviations see Table 4)

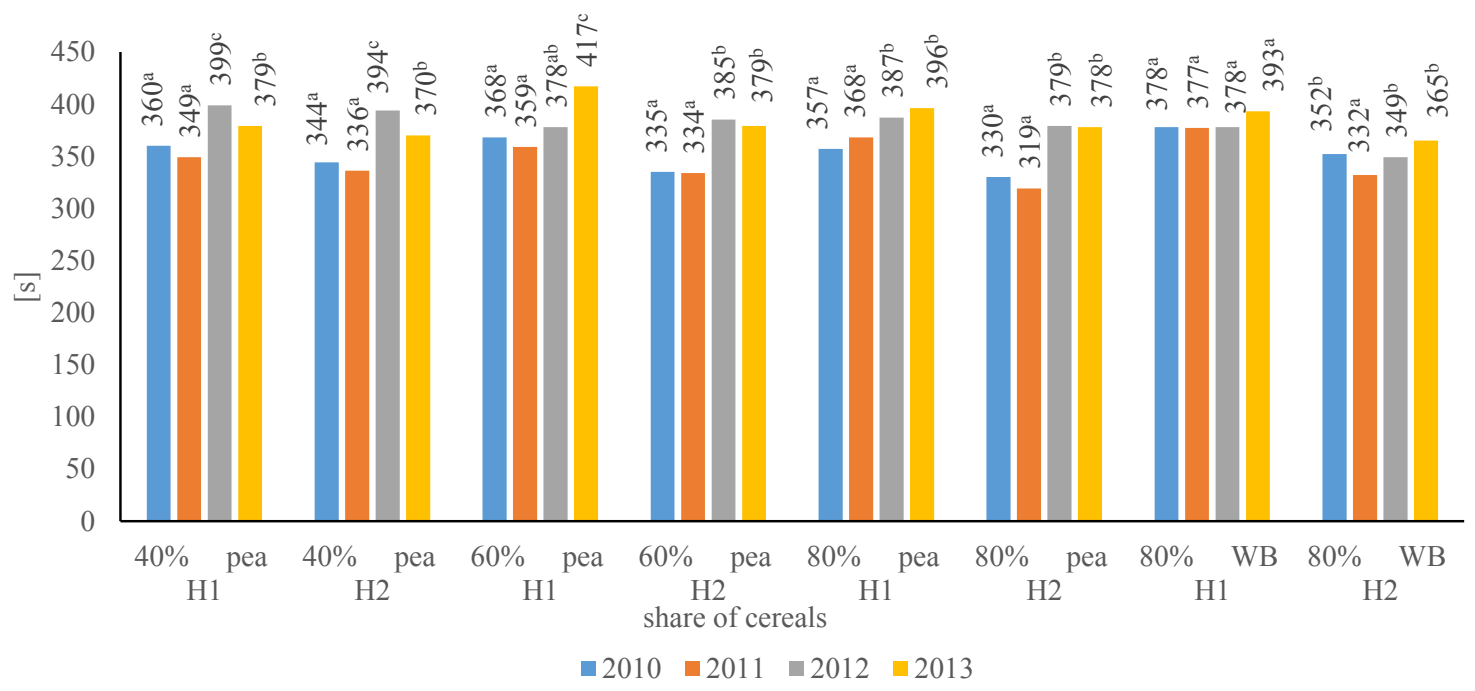

Figure 4. The falling number [s] of winter wheat grain in crop rotations with different share of cereals (abbreviations see Table 4) 
tion between fertilisation and particular years and the interaction between the share of cereals and particular years (Table 5). In 2010-2013, the average grain yield of winter wheat after crop pea in treatment $\mathrm{H}_{1}$ (a combination of mineral fertilisation with the use of organic fertiliser Veget ${ }^{\mathbb{Q}}$ ) was statistically significantly higher $7.10 \mathrm{t} / \mathrm{ha}$ than in treatment $\mathrm{H}_{2}$ (6.66 t/ha). Similarly, Wozniak and Gos (2014) observed the enhancing of grain yield of winter wheat by the amount of $150 \mathrm{~kg} / \mathrm{ha}$ compared to the amount of nitrogen $90 \mathrm{~kg} / \mathrm{ha}$. Užík et al. (2009) indicated that the modern cultivars of winter wheat require a minimal rate from 80 to $120 \mathrm{~kg} / \mathrm{ha} \mathrm{N}$ to guarantee quality parameters for food utilisation. The positive effect of higher doses of nitrogen on higher yield of dry matter of winter wheat was confirmed by Žák et al. (2012). Similarly, Hejcman and Kunzová (2010) recorded the positive annual yield growth of grain from 7.1 to $72.8 \mathrm{~kg} / \mathrm{ha}$ following the application of 46 to $121 \mathrm{~kg} / \mathrm{ha} \mathrm{N}$. Tanács et al. (2010) introduced that increasing fertiliser doses tendentiously improved the values of wet gluten, baking value and

T a b 1 e 6

The influence of fertilisation and share of cereals on wet gluten content and GI and of winter wheat (analysis of variance)

\begin{tabular}{|l|c|r|r|r|r|r|r|r|r|c|}
\hline \multirow{2}{*}{ Factor } & \multicolumn{4}{|c|}{ Wet gluten content [\%] } & \multicolumn{6}{c|}{ Gluten index } \\
\cline { 2 - 11 } & $d f$ & MS & F & $P$ & $L S D_{0.05}$ & $d f$ & MS & F & $P$ & $L S D_{0.05}$ \\
\hline Fertilisation (A) & 1 & 264.0 & 73.19 & ++ & 0.77 & 1 & 753.8 & 3.99 & ++ & 2.18 \\
SCCR (B) & 2 & 13.4 & 3.71 & + & 1.14 & 2 & 168.5 & 3.14 & ++ & 3.21 \\
A $\times$ B & 2 & 9.0 & 2.49 & - & - & 2 & 113.0 & 3.14 & + & 5.56 \\
Year (C) & 3 & 778.1 & 215.72 & ++ & 1.45 & 3 & $9,136.3$ & 2.75 & ++ & 4.08 \\
A $\times$ C & 3 & 24.4 & 6.76 & ++ & 2.43 & 3 & 218.8 & 2.75 & ++ & 6.85 \\
B $\times$ C & 6 & 10.0 & 2.77 & + & 0.77 & 6 & 108.8 & 2.24 & ++ & 9.07 \\
Error & 69 & 32.1 & - & - & - & 69 & 339.6 & - & - & - \\
Total & 95 & 3.6 & - & - & - & 95 & 28.7 & - & - & - \\
\hline
\end{tabular}

SCCR - share of cereals in crop rotation; $d f$-degrees of freedom; MS - average squares, F - F-test; $P$ - effect of a factor significant at the level $0.05 ; L S D_{0.05}$ - least significant difference at the level $\alpha=0.05$; GI - gluten index

T a b 1 e 7

The influence of fertilisation and share of cereals on falling number and sedimentation index of winter wheat (analysis of variance)

\begin{tabular}{|l|c|c|c|c|c|c|c|c|c|c|}
\hline \multirow{2}{*}{ Factor } & \multicolumn{4}{|c|}{ Falling number [\%] } & \multicolumn{4}{c|}{ Sedimentation index according Zeleny [ml] } \\
\cline { 2 - 11 } & $d f$ & MS & F & $P$ & $L S D_{0.05}$ & $d f$ & MS & F & $P$ & $L S D_{0.05}$ \\
\hline Fertilisation (A) & 1 & 9204.2 & 3.99 & ++ & 8.86 & 1 & 137.76 & 24.32 & ++ & 0.97 \\
SCCR (B) & 1 & 184.8 & 3.14 & - & - & 1 & 16.53 & 2.92 & - & - \\
$\mathrm{A} \times \mathrm{B}$ & 1 & 495.1 & 3.14 & - & - & 1 & 5.95 & 1.05 & - & - \\
Year (C) & 3 & $13,080.4$ & 2.75 & ++ & 16.55 & 3 & 1266 & 223.48 & ++ & 1.81 \\
$\mathrm{~A} \times \mathrm{C}$ & 3 & 873.5 & 2.75 & - & - & 3 & 24.15 & 4.26 & ++ & 3.04 \\
$\mathrm{~B} \times \mathrm{C}$ & 3 & 553.4 & 2.24 & - & - & 3 & 8.77 & 1.55 & - & - \\
Error & 63 & 969.4 & - & - & - & 63 & 48.28 & - & - & - \\
Total & 45 & 472.4 & - & - & - & 45 & 5.67 & - & - & - \\
\hline
\end{tabular}

SCCR - share of cereals in crop rotation; $d f$ - degrees of freedom; MS - average squares, F - F-test; $P$ - effect of a factor significant at the level $0.05 ; L S D_{0.05}-$ least significant difference at the level $\alpha=0.05$ 
technological water absorbance. By $60 \%$ share of cereals in crop rotation, the grain yield was statistically significantly higher $(7.00 \mathrm{t} / \mathrm{ha})$ than by $80 \%$ share of cereals after preceding crop pea $(6.78 \mathrm{t} / \mathrm{ha})$. In 2011, the grain yield of winter wheat after pea was statistically significantly higher $(7.71 \mathrm{t} / \mathrm{ha})$ than in 2010 (7.21 t/ha), 2012 (5.78 t/ha) and 2013 (6.82 t/ha).

In crop rotation with $80 \%$ share of cereals, winter wheat was grown after two preceding crops: pea and winter barley (Figure 1). The grain yield after pea was statistically significantly higher $(6.78 \mathrm{t} / \mathrm{ha})$ than after preceding crop of winter barley (5.76 t/ha). The importance of crop rotation on the grain yield and quality of wheat was confirmed the findings of Borgi et al. (1995). In the wheat-maize rotation, maximum yield and quality was achieved with the highest rate of fertilisers even in the absence of manure. In the rotation that included alfalfa, maximum yield was obtained with the lowest rate of fertilisers but, to optimise the quality, it appeared necessary to apply the highest rate of nitrogen $(200 \mathrm{~kg} / \mathrm{ha})$.

The highest values of wet gluten content were recorded in 2013 (Figure 2). The content of wet gluten in grain was statistically significantly influenced by fertilisation, share of cereals in crop rotations, weather conditions in particular years, interaction between fertilisation and particular years and the interaction between the share of cereals and particular years (Table 6). In our experiment, the wet gluten content growing after pea was statistically significantly higher in treatment $\mathrm{H}_{1}(33.4 \%)$ than in treatment $\mathrm{H}_{2}(30.1 \%)$. Our results correspond to the affirmation of López-Bellindo et al. (2001) that protein content also improved with rising $\mathrm{N}$ fertiliser rates. $\mathrm{N}$ fertiliser proved to be a key factor in determining bread-making quality, and the best strategy available to the farmer for optimising wheat quality. Rieux et al. (2013) mentioned that the content of protein and gluten in grain was higher by fertilisation with mineral fertilizers containing nitrogen, phosphorus and potassium (NPK) than by fertilisation with manure. In crop rotation with $60 \%$ share of cereals, statistically higher wet gluten content was found out $(32.5 \%)$ than in crop rotation with $80 \%$ share of cereals after pea (31.2\%). According to Sip et al. (2013), the wet gluten content is influenced by the level of inputs. They came to the conclusion that the increase of wet gluten content was $5.0 \%$ by conventional tillage and high level of inputs.

Recommended gluten index (GI) value of 70 for wheat bakery products was not achieved in any crop rotation (Figure 3). GI of winter wheat was statistically significantly influenced by fertilisation, share of cereals in crop rotations, climatic conditions in particular years, the interaction between fertilisation

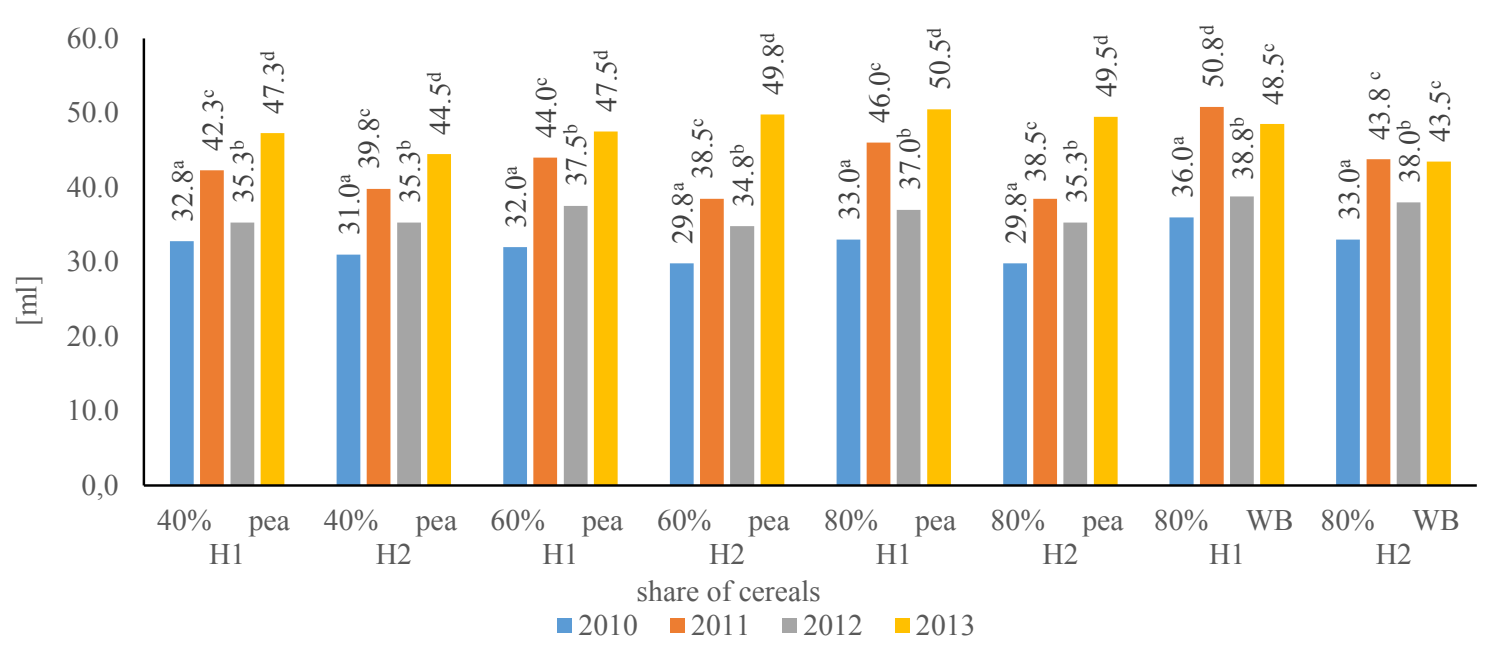

Figure 5. The sedimentation index according to Zeleny of winter wheat grain in crop rotations with different share of cereals (abbreviations see Table 4) 
and share of cereals in crop rotation, the interaction between fertilisation and particular years and the interaction between the share of cereals and particular years (Table 6). By $60 \%$ share of cereals in crop rotations, the substantially lower GI was reached (55.6) than by $40 \%$ share of cereals (59.3) and $80 \%$ share of cereals after pea (59.8). GI of winter wheat in treatment $\mathrm{H}_{2}$ after pea forecrop was statistically significantly higher (61.0) than in treatment $\mathrm{H}_{1}$ (55.4).

The falling number of winter wheat was statistically significantly influenced by fertilisation and climatic conditions in particular years (Table 7). The falling number after pea (Figure 4) was statistically significantly higher $(376 \mathrm{~s})$ in treatment $\mathrm{H}_{1}$ than in treatment $\mathrm{H}_{2}(357 \mathrm{~s})$. Dencic et al. (2013) investigated the effects of dry and wet pre-harvest periods on Hagberg falling number (HFN), a parameter of alpha-amylase activity, and rheological properties including farinograph dough development time, farinograph absorption, resistance to extension, loaf volume and baking score in 30 hexaploid wheat (Triticum aestivum L.) cultivars. They mentioned that in the dry pre-harvest period, HFN was not correlated with rheological properties whereas in the wet pre-harvest period, HFN showed a highly significant positive correlation with farinograph dough development time and baking score. Guarienti et al. (2000) declared that conventional tillage with disc and moldboard plough reduced the falling number compared to no-tillage system and minimum tillage.

The sedimentation index according to Zeleny of winter wheat was statistically significantly influenced by fertilisation, weather conditions in particular years, the interaction between fertilisation and particular years (Table 7). The sedimentation index after preceding crop pea (Figure 5) was statistically significantly higher in treatment $\mathrm{H}_{1}(40.4 \mathrm{ml})$ than in treatment $\mathrm{H}_{2}(38.0 \mathrm{ml})$. Similarly, Sip et al. (2013) observed increase of the sedimentation index according to Zeleny by $6.2 \%$ under conventional tillage with a high input level of nutrients.

\section{CONCLUSION}

The enhancement of grain yield by $1.02 \mathrm{t} / \mathrm{ha}$ was reached by including pea as the preceding crop for winter wheat. Despite unfavourable climatic conditions in 2010-2013, the increase of winter wheat grain yield by $1.68 \mathrm{t} / \mathrm{ha}$ was due to the inclusion of pea as preceding crop of winter wheat and fertilisation $\mathrm{H}_{1}\left(\right.$ mineral of fertilisers + manure Veget $\left.{ }^{\circledR}\right)$. The grain yield by fertilisation level $\mathrm{H}_{2}$ (mineral fertilisation without addition of organic fertiliser Veget ${ }^{\mathbb{B}}$ ) after winter barley forecrop was statistically lower $(5.42 \mathrm{t} / \mathrm{ha}$ ) than the average grain yield of winter wheat by fertilisation $\mathrm{H}_{1}$ (a combination of mineral fertilisation with the use of organic fertiliser Veget ${ }^{\circledR}$ ) and after preceding crop pea $(7.10 \mathrm{t} / \mathrm{ha})$. The share of cereals statistically significantly influenced the grain yield, the wet gluten content and GI. In crop rotation with $60 \%$ share of cereals, statistically higher wet gluten content was found out $(32.5 \%)$ than in crop rotation with $80 \%$ share of cereals after pea (31.2\%). With 40 and $80 \%$ share of cereals in crop rotations, the statistically higher GI was reached (59.3 and 59.8, respectively) than in crop rotation with $60 \%$ share of cereals (55.6). The fertilisation statistically significantly influenced the wet gluten content, GI, falling number and sedimentation index according Zeleny.

Acknowledgements. The study was supported by the Ministry of Agriculture and Rural Development of the Slovak Republic, Project 'Innovation of growing systems in sustainable plant production in variable conditions of environment'(Acronym IPESYS).

\section{REFERENCES}

BIZÍK. J. - FECENKO. J. - KOTVAS. F. - LOŽEK. O. 1998. Metodika hnojenia a výživy rastlín [Methodology of plant fertilization and nutrition]. Nitra : SUA, pp. 112, ISBN 80-967812-1-9.

BORGI, B. - GIORDANI, G. - CORBELLINI, M. - VACCINO. P. - GUERMANDI, M. - TODERI, G. 1995. Influence of crop rotation, manure and fertilizers on bread making quality of wheat (Triticum aestivum L.). In European Journal of Agronomy, vol. 4, no. 1, pp. 37-45. DOI:10.1016/S1161-0301(14)80015-4.

BUREŠOVÁ. I. - PALÍK. S. 2009. Počasí jako faktor pekárenské kvality pšeničného zrna [Weather as a factor of bread-making quality of wheat grain]. In Obilnár̆ské listy, vol. 17, no. 1, pp. 11-14.

CORMIER, F. - FAURE, S. - DUBREUIL, P. - HEUMEZ, E. - BEAUCHENE, K. - LAFARGE, S. - PRAUd, S. 
- LE GOUIS, J. 2013. A multi-environmental study of recent breeding progress on nitrogen use efficiency in wheat (Triticum aestivum, L.). In Theoretical and Applied genetics, vol. 126, no. 12, pp. 3035-3048.

DENCIC, S. - DE PAUW, R. - KOBILJSKI, B.- MOMCILOVIC, 2013. Hagberg falling number and rheological properties of wheat cultivars in wet and dry preharvest periods. In Ammonium as sole $\mathrm{N}$ source improves grain quality in wheat. In Plant Production Science, vol. 16, no. 4, pp. 342-351.

FUERTES-MENDIZABAL, T. - GONZALEZ-TORRALBA, J. - ARREGUI, L.M. - GONZALES-MORO, M.B. - ESTAVILLO, J.M. 2013. Ammonium as sole $\mathrm{N}$ source improves grain quality in wheat. In Journal of the science of food and agriculture, vol. 93, no. 9, pp. 2162-2171.

GARRIDO-LESTACHE, E. - LÓPEZ-BELLIDO, R.J. - LÓPEZ-BELLIDO, L. 2004. Effect of $\mathrm{N}$ rate, timing and splitting and $\mathrm{N}$ type on bread-making quality in hard red spring wheat under rainfed Mediterranean conditions. In Field Crop Research, vol. 85, pp. 213-236.

GUARIENTI, E.M. -PEREIRA DOS SANTOS, H. BARRENECHE LHAMBY, J.C. 2000. Influence of soil management and crop rotation on characteristics that define the industrial quality of wheat. In Pesquisa Agropecuária Brasileira, Brasília, vol. 35, no. 12 , pp. 2375-2382. doi.org/10.1590/S0100$204 X 2000001200007$.

HEJCMAN, M. - KUNZOVÁ, E. 2010. Sustainability of winter wheat production on sandy -loamy Cambisol in the Czech Republic: Results from a long-term fertilizer and crop rotation experiment. In Field Crop Research, vol. 115, pp.191-199.

HEJCMAN, M. - KUNZOVÁ, E. 2010. Sustainability of winter wheat production on sandy - loamy Cambisol in the Czech Republic: Results from a long-term fertilizer and crop rotation experiment. In Field Crop Research, vol. 115, pp. 191-199.

LÓPEZ-BELLIDO, L. - LÓPEZ-BELLIDO, R. J. - CASTILLO, J. E. - LÓPEZ-BELLIDO, F.J. 2001. Effects of long-term tillage, crop rotation and nitrogen fertilization on bread-making quality of hard red spring wheat. In Field Crop Research, vol. 72, pp.197-210.

RIEUX, C.M. - VANASSE, A. - CHANTIGNY, M.H. GELINAS, P. - ANGERS, D.A. - ROCHETTE, P. ROYER, I. 2013. Yield and bread-making potential of spring wheat under mineral and organic fertilization. In Crop Science, vol. 53, no. 3, pp. 1139-1147.

SIP, V. - VAVERA, R. - CHRPOVÁ, J. - KUSÁ, H. RŮŽEK, P. 2013. Winter wheat yield and quality related to tillage practice, input level and environmental conditions. In Soil \& Tillage research, vol. 132, pp. 77-85.

STEPIEN, V. - WOJTKOWIAK, K. 2013. Composition of gluten proteins in spring and winter wheat grain cultivated under conditions of varied fertilization. In Acta Agriculturae Scandinavica Section B-soil and Plant Science, vol. 63, pp. 588-594.

STN EN ISO 3093. 2010. Pšenica, raž a múky z nich, tvrdá pšenica a múka z dvrdej pšenice - semolina.
Stanovenie čísla poklesu podla Hagberga-Pertena [Wheat, rye and flour of them, hard wheat (Triticum durum) and flour of hard wheat - semolina. Determination of falling number according Hagberg-Perten] SÚTN : Bratislava, 2010, $20 \mathrm{pp}$.

ICC Standard No.155. 1994. Determination of Wet Quantity and Quality (Gluten index ac. to Perten) of Whole Meal and Wheat Flour (Triticum aestivum). International Association for Cereal Science and Technology. 1994.

STN ST ISO 5529. 2008. Pšenica. Stanovenie sedimentačného indexu podl'a Zelenyho [Wheat. Determination of sedimentation index according Zeleny] SÚTN : Bratislava, 2008, $16 \mathrm{pp}$.

STN 461100-2. 2003. Potravinárske obilniny. Čast' 2: Zrno potravinárskej pšenice letnej [Cereals for human consumption. Part 2: Grain of wheat for human consumption]. SÚTN : Bratislava, 2003, 8 pages.

SURMA, M. - ADAMSKI, T. - BANASZAK, Z. - KASZMAREK, Z. - KUCZYNSKA, A. - MAJCHER, M. - LUGOWSKA, B. - OBUCHOWSKI, W. - SAMANOWICZ, B. - KRYSTKOWIAK, K. 2012. Effect of genotype, environment and their interaction on quality parameters of wheat breeding lines of diverse grain hardness. In Plant Production Science, vol. 15, no. 3, pp. 192-203.

TANÁCS, L. - GREGOVÁ, E. - BODNÁR, K. - LANTOS, F. - MONOSTORI, T. 2010. Effect of fertilizers and fungicides applied in various doses and combinations on baking characteristics of wheat. In Cereal Research Communication, vol. 38, no. 4, pp. 579-588. UŽÍK, M. - ŽOFAJOVÁ, B. - HANKOVÁ, A. 2009. Breeding progress in grain yield and quality of winter wheat cultivars. In Agriculture (Pol'nohospodárstvo), vol. 55 , no. 1 , pp. $26-32$.

WOZNIAK, A. - GOS, M. 2014. Yield and quality of spring wheat and soil properties as affected by tillage system. In Plant, Soil and Environment, vol. 60, no. 4, pp. 141-145.

ZHOU, O.P. - BISWAS, D.K. - MA, B.L. 2013. Comparisons among cultivars of wheat, hulless and hulled oats: Dry matter, $\mathrm{N}$ and $\mathrm{P}$ accumulation and partitioning as affected by $\mathrm{N}$ supply. In Journal of Plant $\mathrm{Nu}$ trition and Soil Science, vol. 176, no. 6, pp. 929-941.

ŽÁK, Š. - MACÁK, M. - HAŠANA, R. 2012. Influence of soil cultivation technologies and fertilisation on productivity and energy production of arable crops. In Agriculture (Polnohospodárstvo), vol. 58, no. 1, pp. 25-33.

Received: September 12, 2014 